\title{
Renewable Biofuel Production Using Red Ginseng Marc in Microbial Fuel Cells
}

\author{
Sung Jun Jang1, Immanuel H. Anaborne'2, Jacqueline E. Chang3, Seohyun Shim4, \\ Sue Min Shin ${ }^{5}$, Justin Kong6, Seunghan Baek ${ }^{7}$, Kunmin Kim ${ }^{8}$, Abraham Ha ${ }^{8}$, Paul S. Chung
}

${ }^{1}$ The Village School, Houston, USA

${ }^{2}$ Oakton High School, Vienna, USA

${ }^{3}$ Redondo Union High School, Redondo Beach, USA

${ }^{4}$ Branksome Hall Asia International School, Jeju-do, Korea

${ }^{5}$ School of Arts \& Sciences, Emory University, Atlanta, USA

${ }^{6}$ School of Arts \& Sciences, Washington University, St. Louis, USA

${ }^{7}$ School of Arts \& Sciences, Johns Hopkins University, Baltimore, USA

${ }^{8}$ Fuzbien Technology Institute, Rockville, USA

Email: paulschung08@gmail.com

How to cite this paper: Jang, S.J., Anaborne, I.H., Chang, J.E., Shim, S., Shin, S.M., Kong, J., Baek, S., Kim, K., Ha, A. and Chung, P.S. (2022) Renewable Biofuel Production Using Red Ginseng Marc in Microbial Fuel Cells. Journal of Sustainable Bioenergy Systems, 12, 1-11.

https://doi.org/10.4236/jsbs.2022.121001

Received: September 3, 2021

Accepted: February 13, 2022

Published: February 16, 2022

Copyright $\odot 2022$ by author(s) and Scientific Research Publishing Inc. This work is licensed under the Creative Commons Attribution International License (CC BY 4.0).

http://creativecommons.org/licenses/by/4.0/

\begin{abstract}
Microbial fuel cell (MFC) is one of the clean and sustainable energy technologies, often referred to as renewable energy, and directly chemical energy contained in organic matter into electrical energy by using the catalytic activity of microorganisms. Cellulosic biomass is a particularly attractive renewable resource for its abundant supply at low cost and its neutral carbon balance. However, methanogenesis had been negatively linked to anaerobic cellulosic power generation in MFCs. Ginseng root is a saponin-rich plant material and red ginseng marc (RGM) has not been reused as a high-value resource for industry although its residue contained both electron donors and saponin, the potential power generation enhancers for MFC. In this study, RGM was supplemented into MFC to evaluate its effects on methanogenesis and power generation. Two-chamber H-type MFCs were established using rumen fluid as anolyte to ferment cellulose at $2 \%(\mathrm{w} / \mathrm{v})$. RGM, the residue from the steam and press process for red ginseng beverage preparation, was freeze-dried and ground to pass $0.5 \mathrm{~mm}$ sieve and added to the anode of MFC at 1\% (w/v; Exp. 1) or $0.1 \%$ (Exp. 2) dose for treatment. Open circuit voltage, voltage and current across an external resistor were measured daily for $10 \mathrm{~d}$. On $\mathrm{d} 10$ of operation, collected biogases were measured for total gas production and analyzed for its components. In Exp. 1, power density was between 44.0 and 97.2 with an average of $83.8 \mathrm{~mW} / \mathrm{m}^{2}$ in 1\% RGM MFCs and was between 45.2 and 76.3 with an average of $61.5 \mathrm{~mW} / \mathrm{m}^{2}$ in control. In Exp. 2, power density was between 44.8 and 75.6 with an average of $60.9 \mathrm{~mW} / \mathrm{m}^{2}$ in $0.1 \%$ RGM MFCs and
\end{abstract}


was between 45.1 and 54.1 with an average of $49.7 \mathrm{~mW} / \mathrm{m}^{2}$ in control. Total gas production for 10d was 563 and $523 \mathrm{~mL}$ for RGM and control, respectively, in Exp 1, and was 546 and $477 \mathrm{~mL}$ for RGM and control, respectively, in Exp 2. Methane took up 58.6 and $67.9 \%$ of total gas for RGM and control, respectively, in Exp 1, and 59.1 and $67.3 \%$ of total gas for RGM and control, respectively, in Exp 2 . Both greater $(\mathrm{P}<0.05)$ power generation less $(\mathrm{P}<0.05)$ methane proportion in RGM MFCs in both Exp. 1 and 2 strongly supports the potential use of red ginseng marc as MFC supplements.

\section{Keywords}

Microbial Fuel Cell, Red Ginseng Marc, Cellulose, Methanogenesis, Electricity

\section{Introduction}

Over $95 \%$ of greenhouse gas emissions including $\mathrm{CO}_{2}$, methane, $\mathrm{CO}$, and nitrous oxide which cause global warming and pollutions result from fossil fuel combustion and natural gas and petroleum systems for energy in the USA [1]. As of 2019 , petroleum, natural gas, and coal represented $80 \%$ of the energy source for primary energy consumption in the USA [2]. Global energy demand also is predicted to grow more than $50 \%$ by 2025 . Thus, greater efforts have been undertaken to develop technologies generating clean and sustainable energy sources that would replace fossil fuels [3]. Clean and sustainable energy, often referred to as renewable energy, is provided from natural sources or processes that are constantly replenished. However, renewable energy contributes only $11 \%$ of primary energy consumption and biomass takes up $43 \%$ of renewable energy resources in the USA [2].

Microbial fuel cell (MFC) is one of renewable energy technology and directly converts biomass to electricity [4]. MFC has shown tremendous electron donor versatility including simple substrates like glucose and organic acids [5], complex substrates such as municipal and industrial wastewaters [6] [7]; and cellulosic biomass [8]. Cellulosic biomass is a particularly attractive renewable resource for its abundant supply at low cost [9] and its neutral carbon balance as biomass [10]. Furthermore, cellulose is a significant component in municipal solid wastes and wastewater [11]. To apply cellulosic biomass effectively into MFC, the anodic process requires efficient cellulose degradation. However, none of the electrochemically active microorganisms have shown cellulose hydrolysis and fermentation activity. Thus, cellulose-degrading microorganisms have been introduced to MFC to provide efficient cellulosic biomass hydrolysis and consequently electron donors to electron transferring bacteria using mixed cellulolytic microbiome from cow [12] [13] or goat [14], and single cellulolytic bacteria [8] [15]. One of the major products from cellulose fermentation is acetic acid, and in most of the MFC, acetate is a preferred substrate because it is inert to- 
wards microbial conversions (fermentation and methanogenesis) and can generate high coulombic efficiency and power output [16]. However, the acetate concentration and anaerobic conditions promote the growth of methanogens which can significantly reduce power generation in MFC. Methanogenesis may deplete electrons from the anode and methanogens may compete for substrates to the exoelectrogens. Acetoclastic methanogens compete for electron donors and hydrogenotrophic methanogens utilize the hydrogen produced in the reactor [17].

Mitigation of methanogenesis has been reported by supplementation of the saponin-rich fraction of plant materials such as tea extract [18], tea seeds [19] in ruminal culture systems, and ginseng roots [20] and bellflower roots [21] in MFCs. Red ginseng marc is the byproduct of steamed ginseng for red ginseng beverage preparation. Ginseng saponins, steroid-like structure with sugar moieties attached, in red ginseng marc after steam and pressure process had not been reported for its concentration as residue or effects as supplements in MFC.

Electric power generation from cellulosic biomass using MFC to reduce the proportion of fossil fuel use in energy production still requires many improvements in practice. Methanogenesis is one of those obstacles and the current study was performed to decrease the methane production in MFC. We hypothesized that saponin-containing plant material byproduct would deplete the methanogenesis and consequently increase the power generation in MFC fermenting cellulose. To achieve this objective and test the hypothesis, the current study investigated the effect of red ginseng marc addition to the anode of MFC containing rumen fluid as anolyte and cellulose as electron donors on biogas production and power generation by conducting two experiments with two concentrations of red ginseng marc.

\section{Materials and Methods}

\subsection{MFC Construction and Operation}

H-type microbial fuel cells consisted of two $125 \mathrm{~mL}$ glass bottles connected through a flange on the sides where a cation exchange membrane (CMI-7000S, Membranes International Inc.) was placed. Two grams of finely ground pine tree (Avicel PH-101, Sigma-Aldrich) was weighed into each one of the bottles which serve as the anode, then $80 \mathrm{~mL}$ of culture medium and $20 \mathrm{~mL}$ strained rumen fluid described below were transferred into each anode. Under flushing of $\mathrm{CO}_{2}$ gas, anode contents were well suspended using a magnetic bar and agitator. The magnetic bar is left in each anode to agitate anode suspension daily during MFC operation. An electrode (Graphite plate) connected with copper wire was placed in the middle of the anode. Copper wire was fixed to butyl rubber stopper which is also fixed with stopcock and Luer locks. To the other bottle which serves as a cathode, $100 \mathrm{~mL}$ of phosphate-buffered saline $\mathrm{pH} 7.4$ (PBS) was transferred. Electrodes identical to anode electrode was placed in the anode chamber. A rubber stopper was placed on the cathode but left open to the air through tubing. A two-liter volume Mylar bag was attached to anode stopper Luer lock to pre- 
vent gas pressure on top in anode compartment during establishment and to collect biogas during the experimental period while cathode stopper was open to the air through Luer lock. Anode and cathode were connected externally through a copper wire with a resistor (300 ohm).

MFCs were placed in a water bath at $37^{\circ} \mathrm{C}$ for operation. After $9 \mathrm{~d}$ pre-experimental operation, treatments were added to anode chamber, and MFCs were operated for $10 \mathrm{~d}$ for each experiment after treatments were received.

\subsection{Anolyte and Treatments Preparation}

For MFC anode compartment inoculum, strained rumen fluid collected from a cow was prepared through filtering through 4 layers of cheesecloth to remove solid debris and bubbling with $\mathrm{CO}_{2}$ gas for $10 \mathrm{~min}$. Strained rumen fluid was stored in a water bath at $37^{\circ} \mathrm{C}$ until inoculated to MFCs. Culture media consisted of $0.048 \% \mathrm{KH}_{2} \mathrm{PO}_{4}, 0.048 \% \mathrm{~K}_{2} \mathrm{HPO}_{4}, 0.048 \%\left(\mathrm{NH}_{4}\right)_{2} \mathrm{SO}_{4}, 0.096 \% \mathrm{NaCl}, 0.1 \%$ Trypticase peptone, $1 \%$ yeast extract, $0.05 \%$ cysteine- $\mathrm{HCl}, 0.013 \% \mathrm{CaCl}_{2} \cdot 2 \mathrm{H}_{2} \mathrm{O}$, $0.02 \% \mathrm{MgSO}_{4} \cdot 7 \mathrm{H}_{2} \mathrm{O}, 0.4 \% \mathrm{Na}_{2} \mathrm{CO}_{3}, 0.1 \%$ sodium fumarate, and $1 \mathrm{ppm}$ of Resazurin and was prepared anaerobically by bubbling with $\mathrm{CO}_{2}$ gas and autoclaved at $121^{\circ} \mathrm{C}$ for $30 \mathrm{~min}$. Culture media was stored in a water bath at $37^{\circ} \mathrm{C}$ until inoculated to MFCs. PBS consisted of $137 \mathrm{mM} \mathrm{NaCl}, 2.7 \mathrm{mM} \mathrm{KCl}, 10 \mathrm{mM}$ $\mathrm{Na}_{2} \mathrm{HPO}_{4}$, and $2 \mathrm{mM} \mathrm{KH} \mathrm{PO}_{4}$ and was autoclaved at $121^{\circ} \mathrm{C}$ for $30 \mathrm{~min}$ and stored at room temperature.

For treatment, freeze-dried red ginseng marc (RGM) was ground to pass through a $0.5 \mathrm{~mm}$ screen. Treatment MFCs received $1 \mathrm{~g}$ or $0.1 \mathrm{~g}$ of RGM was added to the anode for experiments 1 and 2, respectively. Control MFCs received $1 \mathrm{~g}$ or $0.1 \mathrm{~g}$ of celite (Celite ${ }^{\circledR}$, Celite Corp) as the inert placebo for experiments 1 and 2 , respectively.

\subsection{Measurements and Calculation}

Using a digital multimeter, closed-circuit voltage (voltage across a resistor) end point potential (open circuit voltage) and current were measured daily for $10 \mathrm{~d}$ after treatments addition. The following equations were used to calculate power density normalized to electrode surface area.

$$
P=\frac{I V}{A}
$$

where I (A) is the current $(\mathrm{V} / \mathrm{R}(\mathrm{ohm})) ; \mathrm{V}(\mathrm{V})$ is voltage; $\mathrm{R}(\mathrm{ohm})$ is the external resistance; and $\mathrm{A}\left(\mathrm{m}^{2}\right)$ is the projected area of the anode.

The volume of biogas collected in a Mylar bag, produced from the anode, was measured with a glass syringe. Gas composition was analyzed with a gas chromatograph (Agilent 6890).

\subsection{Statistical Analyses}

Experiment 1 (Exp. 1) and Experiment 2 (Exp. 2) were conducted independently and analyzed separately. Exp. 1 and Exp. 2 included $1 \%$ and $0.1 \%$ of RGM, re- 
spectively, but in the same MFC operational condition. Each dose of RGM was compared to its own control in the corresponding experiment.

Power generation measures, fermentation gas production, and gas composition were analyzed using the one-way ANOVA procedure of JPM 14.1.0 (SAS Institute Inc.). Where the significance found $(\mathrm{P}<0.05)$, least square means of for treatments and days were separated using Student's t-test $(\mathrm{P}<0.05)$ and Tuckey HSD $(\mathrm{P}<0.05)$, respectively.

\section{Results and Discussion}

\subsection{Methanogenesis Inhibition}

Methane amount (Figure 1) produced in anode chamber for 10d operation did not change with red ginseng marc $(R G M)$ addition in Exp. $1(P=0.0551)$ or Exp. $2(\mathrm{P}=0.8640)$ at $1 \%$ or $0.1 \%$ of dose, respectively. However, carbon dioxide production (Figure 1) increased with RGM addition at both $1 \%$ (Exp. 1; P = 0.0010 ) and $0.1 \%$ (Exp. 2; $\mathrm{P}=0.0005)$ of doses. Consequently, RGM addition increased total gas production (Figure 1$)$ at both $1 \%(\mathrm{P}=0.0114)$ and $0.1 \%(\mathrm{P}=$ 0.0082) of doses.

Microorganisms ferment carbohydrates for energy production required for growth. The anode in the current study contained cellulose, a polysaccharide, as experimental substrates and also soluble carbohydrates from an anolyte. Cellulose is degraded to cellobiose, a disaccharide of two glucose, then glucose, a monosaccharide by endo- and exo-cellulases as a function of cellulolytic bacteria. Most microorganisms can ferment glucose for their growth in anode in MFC, and the products of anaerobic respiration and fermentation are short-chain organic acids, carbon dioxide, and hydrogen. The organic acid can be further fermented and the ideal glucose decomposition in MFCs is into $\mathrm{CO}_{2}$, proton, and electron in an anode chamber under anaerobic conditions $\left(\mathrm{C}_{6} \mathrm{H}_{12} \mathrm{O}_{6}+6 \mathrm{H}_{2} \mathrm{O} \rightarrow\right.$ $6 \mathrm{CO}_{2}+24 \mathrm{H}^{+}+24 \mathrm{e}^{-}$) [22] by symbiotic microorganisms. However, methane is another end product in most of the MFCs through acetoclastic $\left(\mathrm{CH}_{3} \mathrm{COO}^{-}+\mathrm{H}^{+}\right.$ $\left.\rightarrow \mathrm{CH}_{4}+\mathrm{CO}_{2}\right)$ and hydrogenotrophic $\left(4 \mathrm{H}_{2}+\mathrm{CO}_{2} \rightarrow \mathrm{CH}_{4}+2 \mathrm{H}_{2} \mathrm{O}\right)$ methanogenesis. In either way, the greater total gas production reflects the efficient cellulose fermentation in the current study.

Methane to carbon dioxide ratio (Figure $1(\mathrm{c})$ ) is less in RGM treatments in both $1 \%$ (Exp. 1; $\mathrm{P}=0.0033$ ) and $0.1 \%$ (Exp. 2; $\mathrm{P}=0.0052$ ) of doses and the lower methane to carbon dioxide ratio implies the less $(\mathrm{P}<0.01)$ production of methane per substrates. Although the methane production in volume was similar between control and RGM, methane took out $67.9 \%$ and $67.3 \%$ of total gas in control MFCs while 58.6\% and 59.1\% in RGM MFCs in Exp. 1 and Exp. 2, respectively. Ideally, electrons and the protons should move to the cathode via the external electrical circuit and the cation exchange membrane, respectively, then reduce oxygen and produce water $\left(24 \mathrm{H}^{+}+24 \mathrm{e}^{-}+6 \mathrm{O}_{2} \rightarrow 12 \mathrm{H}_{2} \mathrm{O}\right)$ in the cathode, and generate the current, the flow of electrons. As methane acts as an electron acceptor in an anode, the reduced methane formation in the anode is expected 


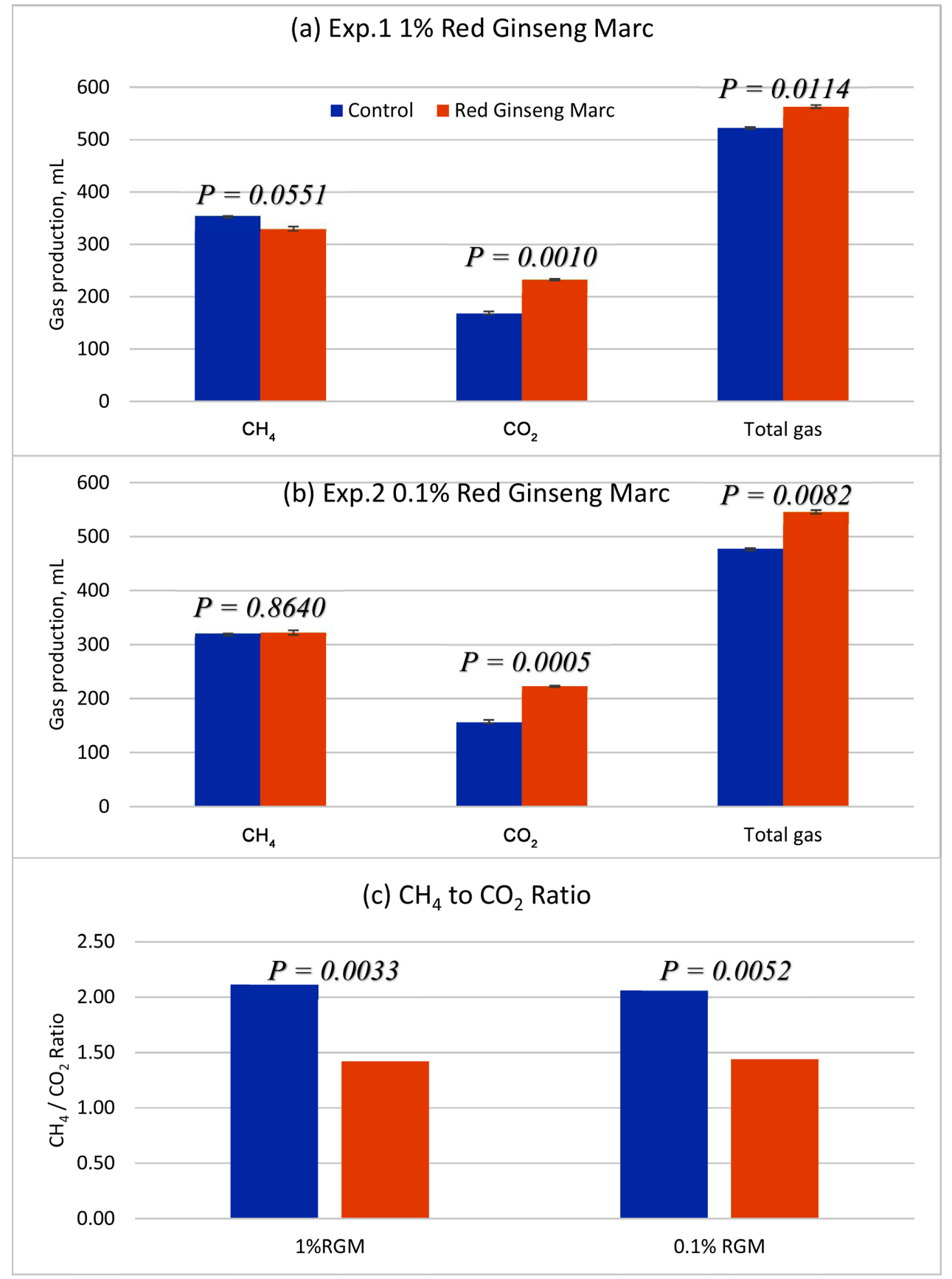

Figure 1. Biogas production in anode of MFCs with red ginseng marc (RGM) addition at the dose of $1 \%$ ((a) Exp. 1) or $0.1 \%$ ((b) Exp. 2). The volumes of methane $\left(\mathrm{CH}_{4}\right)$, carbon dioxide $\left(\mathrm{CO}_{2}\right)$ and total gas produced for $10 \mathrm{~d}$ MFC operation are expressed in $\mathrm{mL}$. $\mathrm{CH}_{4}$ to $\mathrm{CO}_{2}$ ratio (v/v) in Exp. 1 and 2 (c) is a calculation of $\mathrm{CH}_{4}$ volume per $\mathrm{CO}_{2}$ volume produced in anode during $10 \mathrm{~d} \mathrm{MFC}$ operation. $\mathrm{P}$ is probability that two means are not different.

to improve power generation efficiency in MFCs.

\subsection{Electricity Generation}

End point potential in control MFCs in Exp. 1 (Figure 2(a)) was constant $(\mathrm{P}=$ 0.9892 ) during $10 \mathrm{~d}$ operation at the average of $631 \pm 9.1 \mathrm{mV}$. It changed with 
operation time in $1 \%$ RGM MFCs and the average was $765.9 \pm 40.5 \mathrm{mV}$ ranged from 574 to $849 \mathrm{mV}$. It was higher $(\mathrm{P}<0.05)$ on $\mathrm{d} 2$ through $\mathrm{d} 8$ comparing to $\mathrm{d} 0$ in $1 \%$ RGM MFCs. End point potential was also greater $(\mathrm{P}<0.05)$ in $1 \%$ RGM MFCs than control MFCs on d5, d8 and d10 of operation. In Exp. 2 (Figure 2(b)), end point potential in control MFCs was also constant $(\mathrm{P}=0.1389)$ during 10d and the average was $570 \pm 7.9 \mathrm{mV}$, however it changed $(\mathrm{P}=0.0006)$ with operation time in $0.1 \%$ RGM MFCs from $573 \mathrm{mV}$ to $695 \mathrm{mV}$ with the average of

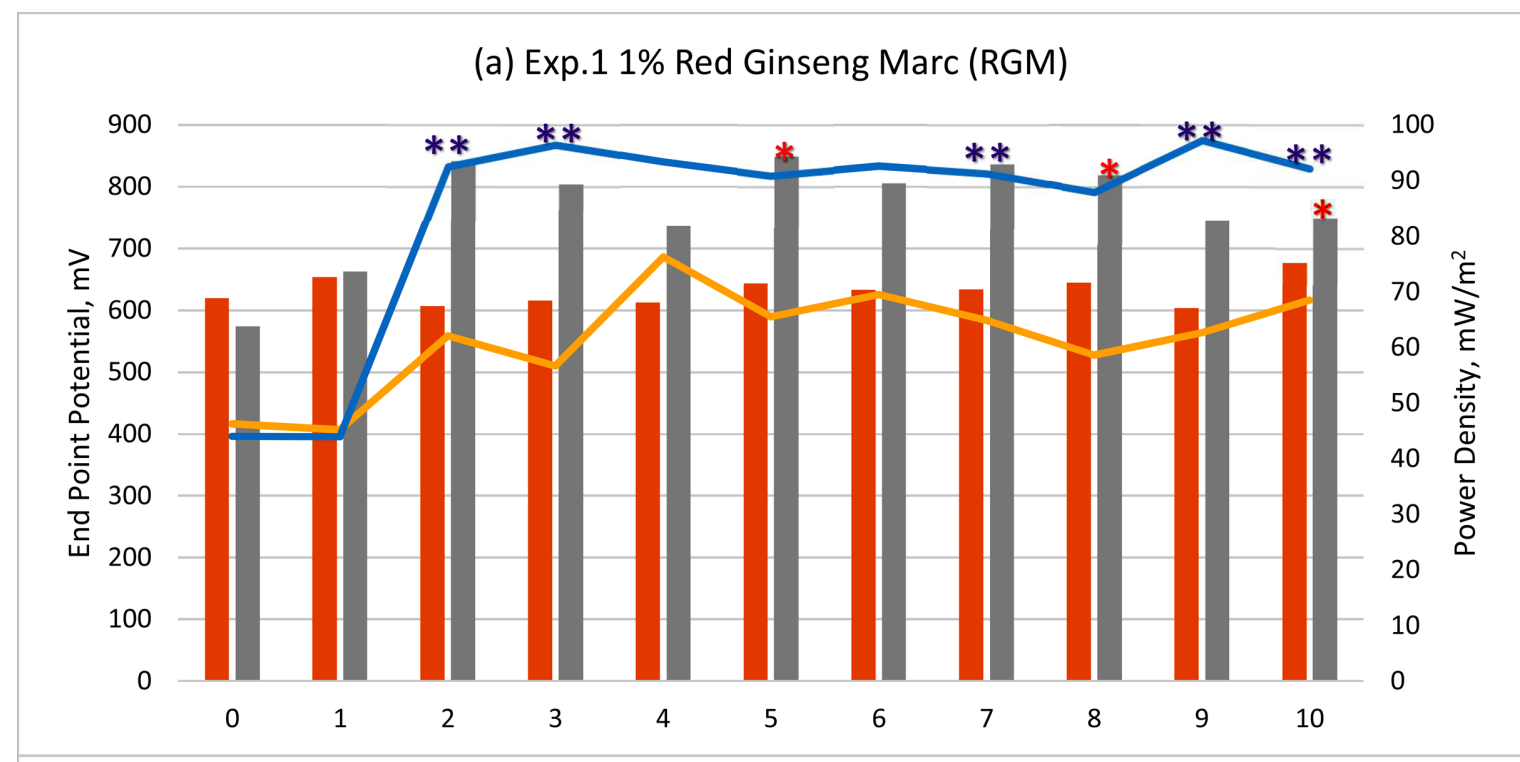

(b) Exp.2 0.1\% Red Ginseng Marc (RGM)
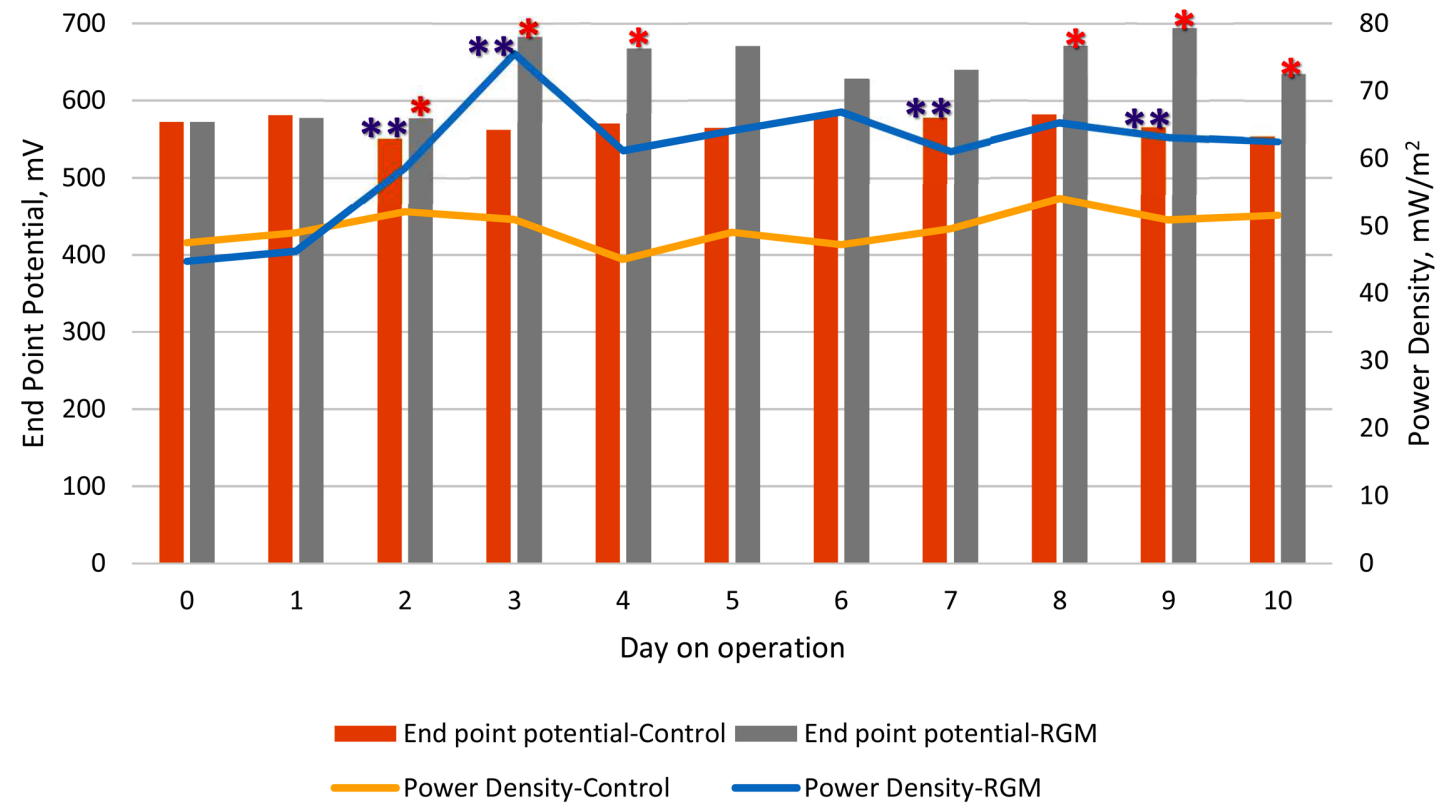

Figure 2. End point potential (bars; $\mathrm{mV}$, open circuit voltage) and power density (lines; $\mathrm{mV} / \mathrm{m}^{2}$ ) in MFCs supplemented with $1 \%$ ((a) Exp. 1) or $0.1 \%$ ((b) Exp. 2) of red ginseng marc (RGM) during 10d operation. ${ }^{\star}$ Means of end point potential between control and RGM differ $(\mathrm{P}<0.05) .{ }^{\star *}$ Means of power density between control and RGM differ $(\mathrm{P}<0.05)$. 
$638 \pm 15.1 \mathrm{mV}$. Comparing to $\mathrm{d} 0$, end point potential increased (P 0.05) on $\mathrm{d} 3$ 5 and d8 - 9 within 0.1\% RGM MFCs. In Exp. 2 0.1\% RGM MFCs had greater (P $<0.05$ ) end point potential than control MFCs on $\mathrm{d} 2-4$ and $\mathrm{d} 8-10$.

Power density in control MFCs in Exp. 1 (Figure 2(a)) increased numerically $(\mathrm{P}=0.0616)$ with the average of $61.5 \pm 6.29 \mathrm{~mW} / \mathrm{m}^{2}$ ranged from 45.2 to 76.3 $\mathrm{mW} / \mathrm{m}^{2}$. Power density in $1 \%$ RGM MFCs changed with operation time and it was greater $(\mathrm{P}<0.05)$ on $\mathrm{d} 2-10$ than $\mathrm{d} 0-1$, the average was $83.8 \pm 2.99$ $\mathrm{mW} / \mathrm{m}^{2}$ with range between 44.0 and $97.2 \mathrm{~mW} / \mathrm{m}^{2} .1 \%$ RGM MFCs (Exp. 1) had greater $(\mathrm{P}<0.05)$ power density than control MFCs on $\mathrm{d} 2,3,7,9$ and 10. In Exp. 2 (Figure $2(\mathrm{~b})$ ), power density was constant $(\mathrm{P}=0.7985)$ over $10 \mathrm{~d}$ of incubation in control MFCs. The average of power density in control MFCs was $49.7 \pm 3.16$ $\mathrm{mW} / \mathrm{m}^{2}$ and the range was between 45.1 and $54.1 \mathrm{~mW} / \mathrm{m}^{2} .0 .1 \% \mathrm{RGM} \mathrm{MFCs}$ had a sort of spike of power density on $\mathrm{d} 3$ and was greater $(\mathrm{P}<0.05)$ than $\mathrm{d} 0-1$. The average of power density in $0.1 \%$ RGM MFCs was $60.9 \pm 3.98 \mathrm{~mW} / \mathrm{m}^{2}$ and ranged from 44.8 to $75.6 \mathrm{~mW} / \mathrm{m}^{2}$. The power density in $0.1 \% \mathrm{RGM} \mathrm{MFCs} \mathrm{was}$ greater $(\mathrm{P}<0.05)$ than control MFCs on $\mathrm{d} 2,3,7$ and 9 (Figure 2(b)).

To determine the bioelectrochemical performances of MFCs, the power generated by the MFC must be normalized to a relevant geometric characteristic of the MFC reactor such as anode surface area or anolyte volume [23]. The power density, normalized to electrode surface area in the current study, the observed values were between 44 and $97 \mathrm{~mW} / \mathrm{m}^{2}$ in Exp. 1 and 2. When sole rumen fluid was used as an anolyte like the current study, the maximum power densities were $55 \mathrm{~mW} / \mathrm{m}^{2}$ from microcrystalline cellulose [24], $100 \mathrm{~mW} / \mathrm{m}^{2}$ from carboxymethyl cellulose [13], and $405 \mathrm{~mW} / \mathrm{m}^{3}$ from Canna indica [14]. Therefore, the performance of MFCs in the current study served as control or treatment can be considered as acceptable or better than previous reports. Furthermore, potassium ferricyanide solution $\left(50 \mathrm{mM} \mathrm{K}_{3} \mathrm{Fe}(\mathrm{CN})_{6}\right)$ was used as the catholyte to enhance oxygen reduction in the cathode in the previous reports while only PBS was used in the current study to maintain the environmental friendly conditions.

Power generation was improved $(\mathrm{P}<0.0001)$ by red ginseng marc at both $1 \%$ or $0.1 \%$ dose and the average of power density and end point potential were shown on Figure 3(a) and Figure 3(b), respectively. For power density (Figure $3(\mathrm{a})), 36 \%$ and $22 \%$ is increased $(\mathrm{P}<0.0001)$ by $1 \%$ or $0.1 \%$ RGM supplementation, respectively. A $21 \%$ or $12 \%$ of higher end point potential was generated by $1 \%$ or $0.1 \%$ RGM supplementation (Figure $3(\mathrm{~b})$ ), respectively. These improvements in means for $10 \mathrm{~d}$ represent the daily measurement point while the power generation in MFCs was a continuous reaction during the operation, thus the measured improvement also reflects the total power generation improvements even with different values and units. Two experiments, Exp. 1 and Exp. 2, were conducted independently, therefore two different doses of red ginseng marc could not be compared. In each experiment, comparing to its own control MFCs, 1\% RGM had shown bigger improvements for both power density and end point potential than $0.1 \%$ RGM, however total gas production improvement 
(a) Power Density for 10d Operation

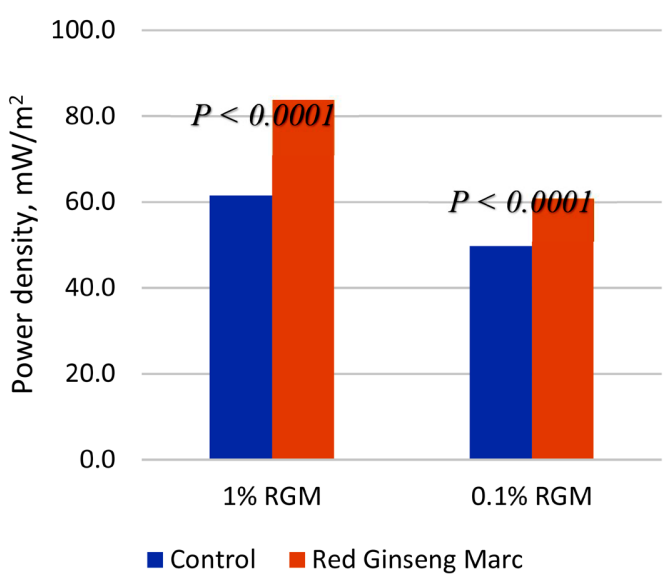

(b) End Point Potential for 10d Operation

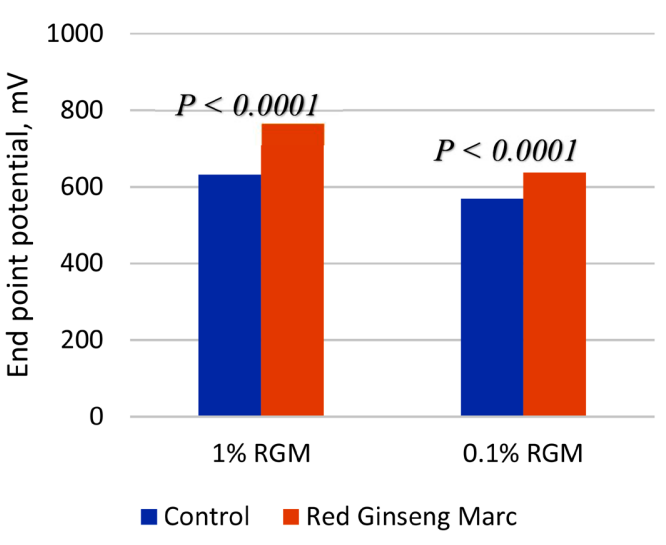

Figure 3. Least Square Means of end point potential (open circuit voltage) and power density in MFCs supplemented with 1\% ((a) Exp. 1) or 0.1\% ((b) Exp. 2) of red ginseng marc (RGM) during 10d operation.

was $7.7 \%$ in $1 \%$ RGM and $14.4 \%$ in $0.1 \%$ RGM.

In conclusion, methane production inhibited, and power generation increased by the red ginseng marc addition at $1 \%$ or $0.1 \%$ dose to the anode of MFC generating electricity from cellulose using rumen microorganisms.

\section{Conclusion}

Red ginseng marc, a byproduct of saponin-rich plant materials decreased the methanogenesis and increased the total gas production, and improved the power generation by $36 \%$ or $22 \%$ as a supplement at $1 \%$ or $0.1 \%$ dose, respectively. As demand for renewable biofuel, clean and sustainable energy, is growing, MFC is becoming more attractive as such a technology and has been being studied for bioelectrochemical performances with expanded electron donor resources. The current study provided evidence that methanogenesis, the intrinsic disadvantage of cellulosic power generation, would be depleted with the red ginseng marc addition or saponin-rich material supplementation to microbial fuel cells.

\section{Acknomledgements}

The authors acknowledge the Fuzbien Technology Institute and Youth with Talents for sponsoring this research project (FTI-9-2020).

\section{Conflicts of Interest}

The authors declare no conflicts of interest regarding the publication of this paper.

\section{References}

[1] EPA (2018) Inventory of U.S. Greenhouse Gas Emissions and Sinks: 1990-2018. https://www.epa.gov/sites/production/files/2016-04/documents/us-ghg-inventory-2 
018-main-text.pdf

[2] EIA (U.S. Energy Information Administration) (2020) Monthly Energy Review April 2020. https://www.eia.gov/energyexplained/renewable-sources

[3] Levin, D.B., Islam, R., Cicek, N. and Sparling, R. (2006) Hydrogen Production by Clostridium thermocellum 27405 from Cellulosic Biomass Substrates. International Journal of Hydrogen Energy, 31, 1496-1503. https://doi.org/10.1016/j.ijhydene.2006.06.015

[4] Logan, B.E. and Regan, J.M. (2006) Microbial Fuel Cells-Challenges and Applications. Environmental Science \& Technology, 40, 5172-5180.

https://doi.org/10.1021/es0627592

[5] Bond, D.R. and Lovley, D.R. (2003) Electricity Production by Geobacter Sulfureducens Attached to Electrodes. Applied and Environmental Microbiology, 69, 1548-1555. https://doi.org/10.1128/AEM.69.3.1548-1555.2003

[6] Min, B., Kim, J., Oh, S., Regan, J.M. and Logan, B.E. (2005) Electricity Generation from Swine Wastewater Using Microbial Fuel Cells. Water Research, 39, 4961-4968. https://doi.org/10.1016/j.watres.2005.09.039

[7] Aelterman, P., Rabaey, K., Clauwaert, P. and Verstraete, W. (2006) Microbial Fuel Cells for Wastewater Treatment. Water Science \& Technology, 54, 9-15.

https://doi.org/10.2166/wst.2006.702

[8] Hassan, S.H., Kim, Y.S. and Oh, S.E. (2012) Power Generation from Cellulose Using Mixed and Pure Cultures of Cellulose-Degrading Bacteria in a Microbial Fuel Cell. Enzyme and Microbial Technology, 51, 269-273. https://doi.org/10.1016/j.enzmictec.2012.07.008

[9] Lynd, L.R., Weimer, P.J., van Zyl, W.H. and Pretorius, I.S. (2002) Microbial Cellulose Utilization: Fundamentals and Biotechnology. Microbiology and Molecular Biology Reviews, 66, 506-577. https://doi.org/10.1128/MMBR.66.3.506-577.2002

[10] Niessen, J., Schröder, U., Harnisch, F. and Scholz, F. (2005) Gaining Electricity from in Situ Oxidation of Hydrogen Produced by Fermentative Cellulose Degradation. Letters in Applied Microbiology, 41, 286-290. https://doi.org/10.1111/j.1472-765X.2005.01742.x

[11] Perlack, R., Wright, L.L., Turhollow, A.F., Graham, A.F., Stokes, B.J. and Erbach, D.C. (2005) Biomass as Feedstock for a Bioenergy and Bioproducts Industry: The Technical Feasibility of a Billion-Ton Annual Supply. Oak Ridge National Laboratory, Oak Ridge. https://doi.org/10.2172/1216415

[12] Chung, R., Kang, E.Y., Shin, Y.J., Park, J.J., Park, P.S., Han, C.H., Kim, B., Moon, S.I., Park, J. and Chung, P.S. (2019) Development of a Consolidated Anaerobic Digester and Microbial Fuel Cell to Produce Biomethane and Electricity from Cellulosic Biomass Using Bovine Rumen Microorganisms. Journal of Sustainable Bioenergy Systems, 9, 2. https://doi.org/10.4236/jsbs.2019.92002

[13] Wang, Z., Hong, Q., Shu, M., Chen, Y., Dong, L.X. and Ming, Y. (2014) Rumen Bacteria Convert Cellulose into Electricity in Two-Chamber Microbial Fuel Cell. Journal of Chemical and Pharmaceutical Research, 6, 727-732.

[14] Zang, G.-L., Sheng, G.-P., Tong, Z.-H., Liu, X.-W., Teng, S.-X. and Li, W.-W. (2010) Direct Electricity Recovery from Canna indica by an Air-Cathode Microbial Fuel Cell Inoculated with Rumen Microorganisms. Environmental Science \& Technology, 44, 2715-2720. https://doi.org/10.1021/es902956e

[15] Chung, R., Moon, D., Chang, Y., Chung, D., Kong, T. and Kim, J. (2018) The Cellulolytic Bacteria $R$. albus for Improving the Efficiency of Microbial Fuel Cell. Journal of Sustainable Bioenergy Systems, 8, 36-46. 
https://doi.org/10.4236/jsbs.2018.82003

[16] Pant, D., Bogaert, G.V., Diels, L. and Vanbroekhoven, K. (2010) A Review of the Substrates Used in Microbial Fuel Cells (MFCs) for Sustainable Energy Production. Bioresource Technology, 101, 1533-1543.

https://doi.org/10.1016/j.biortech.2009.10.017

[17] Rago, L., Guerrero, J., Baeza, J.A. and Guisasola, A. (2015) 2-Bromoethanesulfonate Degradation in Bioelectrochemical Systems. Bioelectrochemistry, 105, 44-49. https://doi.org/10.1016/j.bioelechem.2015.05.001

[18] Guo, Y.Q., Liu, J.-X., Lu, Y., Zhu, W.Y., Denman, S.E. and McSweeney, C.S. (2008) Effect of Tea Saponin on Methanogenesis, Microbial Community Structure and Expression of mcrA Gene, in Cultures of Rumen Microorganisms. Letters in Applied Microbiology, 47, 421-426.

https://doi.org/10.1111/j.1472-765X.2008.02459.x

[19] Jadhav, R.V., Kannan, A., Bhar, R., Sharma, O.P., Gulati, A., Rajkumar, K., Mal, G., Singh, B. and Verma, M.R. (2018) Effect of Tea (Camellia sinensis) Seed Saponins on in Vitro Rumen Fermentation, Methane Production and True Digestibility at Different Forage to Concentrate Ratios. Journal of Applied Animal Research, 46, 118-124. https://doi.org/10.1080/09712119.2016.1270823

[20] Kim, W., Lee, P., Kim, T.W., Kim, G., Chung, J.S., Joo, J.A. and Chung, S.-J. (2015) Impact of Korean Ginseng (Panax Ginseng) on Power Generation of Microbial Fuel Cells. Journal of Chemistry and Chemical Engineering, 9, 448-453. https://doi.org/10.17265/1934-7375/2015.07.003

[21] Park, J.-I., Kim, H., Go, D.K., Park, P.S., Lee, S.H., Koh, M.J., Jo, J., Lee, D., Lee, S. and Chung, P.S. (2019) Enhancement of Power Generation in Microbial Fuel Cells through Supplementation of Platycodon grandiflorum in Doraji Roots. Journal of Sustainable Bioenergy Systems, 9, 169-178. https://doi.org/10.4236/jsbs.2019.94011

[22] Pham, T.H., Rabaey, K., Aelterman, P., Clauwaert, P., De Schamphelaire, L., Boon, N. and Verstraete, W. (2006) Microbial Fuel Cells in Relation to Conventional Anaerobic Digestion Technology. Engineering in Life Sciences, 6, 285-292. https://doi.org/10.1002/elsc.200620121

[23] Choi, S. (2015) Microscale Microbial Fuel Cells: Advances and Challenges. Biosensors Bioelectronics, 69, 8-25. https://doi.org/10.1016/j.bios.2015.02.021

[24] Rismani-Yazdi, H., Christy, A.D., Dehority, B.A., Morrison, M., Yu, Z. and Tuovinen, O.H. (2007) Electricity Generation from Cellulose by Rumen Microorganisms in Microbial Fuel Cells. Biotechnology and Bioengineering, 97, 1398-1407. https://doi.org/10.1002/bit.21366 